\title{
ECOLOGIC MONITORING OF VOLATILE ORGANIC COMPOUNDS IN OPERATION ROOM DURING SEVOFLURANE ANAESTHESIA FOR OOCYTE RETRIEVAL \\ Potievskaya V. ${ }^{1}$, Ushakov I. ${ }^{2}$
}

${ }^{1}$ National Medical Research Radiological Center, Dept of Anaesthesiology \& Intensive Care, Moscow, Russian Federation,

${ }^{2}$ Medical Center Moskvorechye, Dept of Anaesthesiology, Moscow, Russian Federation

Background and Goal of Study: Ecologic problems in anesthesiology have not been yet properly studied. However environmental pollution by anesthetics may influence on condition of medical stuff and patients. Human oocytes are especially sensitive to different contaminants, so monitoring of air quality in operation room for assisted reproduction technology procedures is important for successful in vitro fertilization (IVF) $[1,2]$. The purpose of the study was to determine safety of inhalational anesthetics by dynamic measurements of volatile organic compounds (VOC) in different areas of operating room.

Materials and methods: This was a pilot prospective clinical study. Measurements of air pollution were performed using portable photoionization gas analyzer in 5 areas of operating room where oocyte retrieval was conducted during 7 working days in areas of the stuff (embryologist, gynecologist, anesthetist and anesthesiologist) and near the patient's head. Inspiratory concentration of sevoflurane was $7-8 \%$, gas flow changed from $6 \mathrm{l} / \mathrm{min}$ to $2 \mathrm{l} / \mathrm{min}$. VOC were assessed at least 3 times during induction, support of anaesthesia and awakening periods. Statistical analysis was performed using nonparametric sign test and Wilkokson T-criterium for $95 \%$ confidence interval.

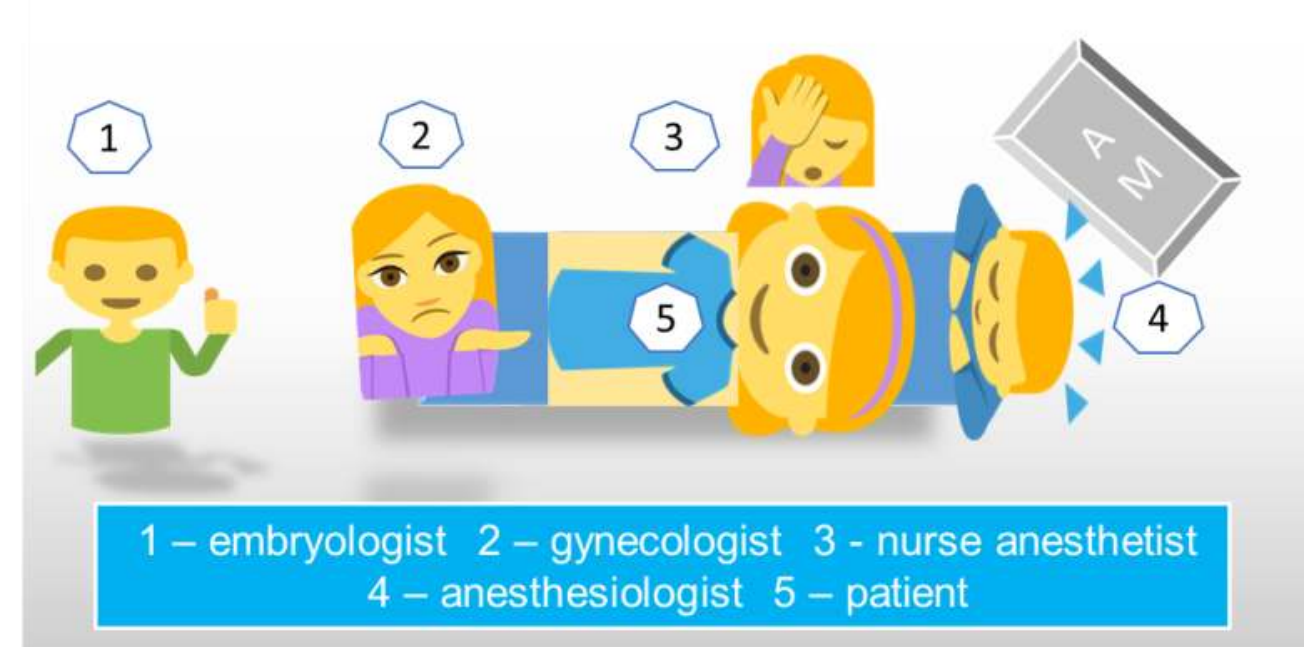

Results and discussion: No air pollution was determined during induction of anesthesia in all measuring points. There was no air pollution in the areas of embryologist and gynecologist during all the periods of anaesthesia. Data from the other areas demonstrated VOC increase twice more significant in the awakening period comparing with induction of anesthesia (VOC increased from $0.21 \pm 0.05$ to $0.72 \pm 0.12 \mathrm{mg} / \mathrm{m}^{3}$ in the anesthetist area, from $0.68 \pm 0.12$ to $1.50 \pm 0.18 \mathrm{mg} / \mathrm{m}^{3}$ in the anesthesiologist area and from $1.02 \pm 0.16$ to $2.61 \pm 0.28 \mathrm{mg} / \mathrm{m}^{3}$ near the patient, $\mathrm{p}<0.05)$ - fig. All the values were below maximal allowable VOC concentration $\left(16.6 \mathrm{mg} / \mathrm{m}^{3}=2 \mathrm{ppm}\right)$.

Conclusion(s): Air pollution during oocytes retrieval with sevoflurane anesthesia was not significant in all areas of operating room. VOC monitoring appeared to be an effective method of prevention air pollution.

Tab. Indicators of air pollution in the operating room at various stages of anesthesia, $\mathrm{mg} / \mathrm{m}^{3}(\mathrm{M} \pm \mathrm{m} ; \mathrm{n}=21)$

\begin{tabular}{|c|c|c|c|}
\hline $\begin{array}{c}\text { Measurement } \\
\text { area }\end{array}$ & Induction & $\begin{array}{c}\text { Anesthesia } \\
\text { support }\end{array}$ & Awakening \\
\hline embryologist & 0 & 0 & 0 \\
\hline gynecologist & 0 & 0 & $0.25 \pm 0,07$ \\
\hline anesthetist & 0 & $0.21 \pm 0.05$ & $0.72 \pm 0,12^{*}$ \\
\hline anesthesiologist & 0 & $0.68 \pm 0.12$ & $1.50 \pm 0,18^{*}$ \\
\hline patient & 0 & $1.02 \pm 0.16$ & $2.61 \pm 0,28^{*}$ \\
\hline
\end{tabular}

${ }^{*} p<0.001$.

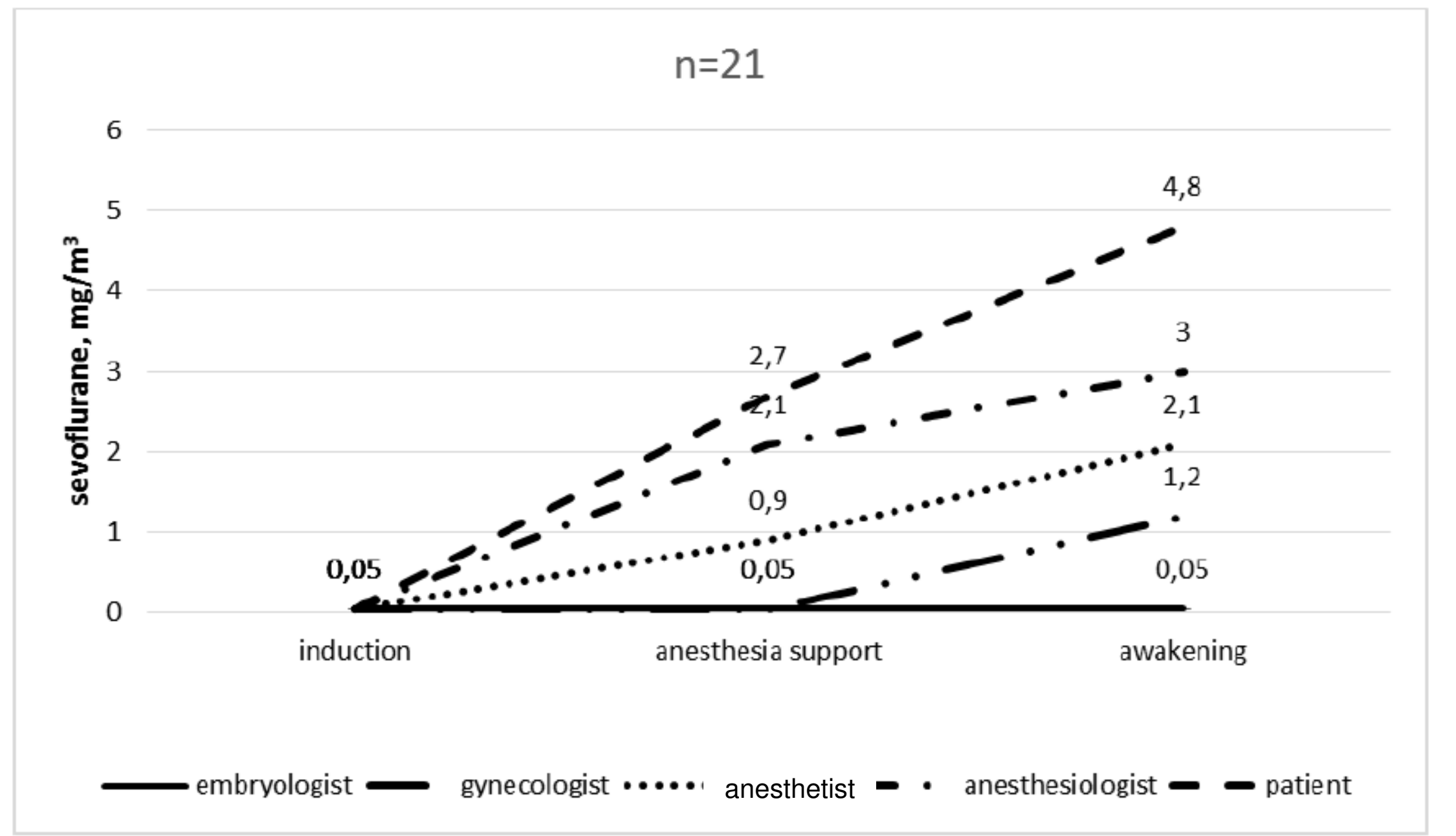

\section{References:}

1. Esteves, SC, Bento, FC., Implementation of air quality control in reproductive laboratories in full compliance with the Brazilian Cells and Germinative Tissue Directive. Reproductive BioMedicine Online (2012), http://dx.doi.org/10.1016/j.rbmo.2012.10.0106.

2. Zuegge KL. Ecological and economical practice for anesthesiologists. Advances in Anesthesia 31 (2013) 21-29. 